Paideusis

\title{
A Response to Thiessen's Academic Freedom in the Religious College and University (1)
}

\section{Clive Beck}

Volume 10, Number 1, 1996

URI: https://id.erudit.org/iderudit/1073206ar

DOI: https://doi.org/10.7202/1073206ar

See table of contents

Publisher(s)

Canadian Philosophy of Education Society

ISSN

0838-4517 (print)

1916-0348 (digital)

Explore this journal

Cite this article

Beck, C. (1996). A Response to Thiessen's Academic Freedom in the Religious

College and University (1). Paideusis, 10(1), 17-23.

https://doi.org/10.7202/1073206ar 


\section{A Response to Thiessen's Academic Freedom in the Religious College and University (1)}

\section{Clive Beck, Ontario Institute for Studies in Education, University of Toronto}

Thiessen's valuable paper on academic freedom and religious colleges and universities is subtitled "Confronting the Postmodernist Challenge." In fact, however, he confronts both the postmodernist and the modernist challenge, attempting to steer a middle course between extreme postmodernist ideas of cultural relativism, on the one hand, and modernist notions of universal truth and absolutely free inquiry, on the other.

\section{Thiessen's Argument}

Thiessen notes that religiously-based colleges and universities are "committed to a certain faith stance" which places constraints on the teaching, the research and even the behaviour of faculty in those institutions. ${ }^{1}$ The problem he addresses is that such constraints "seem to be a blatant violation of the principle of academic freedom" (p. 3). Indeed, a 1988 report of a subcommittee of the American Association of University Professors has said that institutions which impose such limitations on faculty "because of religious or other aims" (p. 4) forfeit "the moral right to proclaim themselves as authentic seats of higher learning" (p. 3).

In defending religious colleges and universities against this charge, Thiessen does not deny that academic freedom in such institutions is limited. Rather, he argues that there are significant limits to academic freedom in secular colleges and universities as well as those set, for example, by politicians, funding agencies, and academic traditions and ideologies. This is the way it must be for "untrammelled inquiry" and "full academic freedom" are impossibilities (p. 6). Inquiry necessarily takes place in an institutional, intellectual, and cultural context which imposes constraints on (but also guides and supports) inquiry. There is no such thing as "a view from nowhere" (Thomas Nagel); inquiry is "inescapably historically and socially context-bound" (Alasdair Macintyre) (p. 7).

Thiessen acknowledges the "postmodernist ring" to this line of argument (p. 13). He endorses postmodernism's attempt "to recapture the preEnlightenment respect for tradition." His critique of the modern ideal of academic freedom "rests on a postmodernist rejection of the agenda begun during the Enlightenment" (p. 9). However, he believes postmodernism has gone too far leading in the direction of "epistemological relativism" and "a conflict model of truth" which is "frankly frightening" (p. 10). He proposes that we adopt a "middle way" (p. 11), a "balance" between institutional limitations on academic freedom and the attempt (which can never be fully successful) "to transcend these limitations" in the "search for universal truth" (p. 10). 


\section{Strengths of the Paper}

1. Rejection of absolute academic freedom

I am frankly persuaded by Thiessen's case against the notion of full academic freedom, and believe he has done a considerable service by presenting that case clearly, systematically, and with a number of original examples. Doubtless, the point has been made before, as Thiessen's citations show; but I think it is often overlooked, as evidenced by continuing prejudice against religious educational institutions and persistent belief in the objectivity and disinterestedness of inquiry in secular institutions. Thiessen's use of postmodernist thought in this context is apt, drawing attention to the way in which knowledge is embedded in historical and cultural assumptions and influenced by political and other interests.

\section{Stress on the importance of community}

Thiessen is rightly critical of the individualism inherent in the modern conception of academic inquiry. In the field of education, the importance of collaboration and collegiality has been a constant theme in the present century. But, too often it is something we recommend for teachers in their training and later pedagogy in schools, not something we practise ourselves. Collaboration is crucial for academics as well, and with it comes necessary constraints on the outcomes of inquiry. To me, one of the most important reasons for having religious schools, colleges, and universities is so that inquiry nourishes and is nourished by community.

\section{A balance between the insights of modernism and postmodernism}

As I myself have argued elsewhere, ${ }^{2}$ a balance is, indeed, what is needed. The postmodernist emphasis on how knowledge and values change over time and vary from culture to culture has been salutary, but there are enduring values (John Dewey), tentative frameworks (Charles Taylor), and similarities (as well as differences) between cultures. Without some generalizations-at least qualified ones-about the nature of reality and the human condition, we lack direction and a basis for intergroup understanding and social justice. We should not exaggerate the similarities between different eras, cultures, and sub-cultures, but neither should we exaggerate the differences.

\section{A relatively positive approach to religious colleges and universities}

As I will explain later, I am not as thoroughly sanguine about religious colleges and universities as Thiessen appears to be. However, as someone who has spent much time recently in religiously-affiliated schools, I believe such institutions are the object of many unfounded prejudices. In so many ways, they are just like secular educational institutions; and, insofar as they differ, it is often in very positive ways: the sense of tradition and community, for example, is a great strength. And, just as religious institutions have been the target of negative stereotyping, secular institutions have been the object of unduly positive stereotyping. Secular colleges and universities today are, indeed, characterized by many of the rigidities, vested interests, and fads noted by Thiessen. 


\section{Proposal of constant review of constraints on freedom}

There is clearly merit in Thiessen's suggestion that "healthy religious educational institutions should ... have mechanisms in place for periodic reflection upon their operating assumptions ... there should be ongoing reflection and critical evaluation of the fundamentals" (p. 13). While I feel Thiessen does not take this idea far enough or develop it in sufficient detail, the basic idea of constant review of constraints on freedom is a sound one for religious and secular institutions alike.

\section{Some Suggestions}

While I believe Thiessen's paper makes a very important contribution, I see some problems in it. These are not fatal flaws, however, and I offer the following constructive criticisms as suggestions for further development of the line of thought Thiessen has presented.

\section{Universal truth should not be retained as an ideal}

Thiessen says that objectivity or "common truth" or "a singular notion of truth" should be kept as an ideal (p. 10). He says that while universal truth cannot in fact be achieved, "the notion of 'a view from nowhere' must be kept as a heuristic principle in order to encourage an open-minded search for truth" (p. 10). But I do not think this is a helpful approach. The fact that truth/reality is diverse, historical, and contextual is not a problem, something that we should as far as possible try to overcome. To hold to this point of view is to retain a prejudice in favour of the eternal and the universal, a prejudice which, after so many centuries of indoctrination, we should be trying energetically to overcome. The point is not that we should be as universalistic as possible, but rather that we should be as universalistic or particularistic as is appropriate in a given context. There is no advantage in general in universality (or the approximation of it). Indeed, there is often an advantage in a local, contextual perspective, as Thiessen's position on the importance of community suggests.

At times, it is useful to test an idea or principle against a universal formulation. In ethics, for example, a common strategy in wrestling with an issue is to ask: "What if everyone did the same?" But I do not believe this should ever by itself settle the matter. Rather, as Charles Allen has said, a universal statement serves as a somewhat artificial "distancing move" which helps us to think more clearly about the matter in hand. ${ }^{3}$ Universalizing, then, is a valuable heuristic device, but seeing universality as the ideal is not. In fact, reflecting on a universalistic alternative will often push us strongly in a more particularistic direction, and rightly so.

We might note in this context that Christianity-the religion in question in the case of most North American religiously-affiliated colleges and universities-tends to have a presumption in favour of the universal, and this has often proved to be a great problem both for Christians themselves and for people of other religions who have come in contact with Christianity. When discussing Christian colleges and universities, then, it is especially important to reject the assumption that universality is the ideal. 
2. We should not be too positive toward the pre-Enlightenment period

As we saw earlier, Thiessen is attracted to postmodernism because of what he sees as its "attempt to recapture the pre-Enlightenment respect for tradition" and its "rejection of the agenda begun during the Enlightenment." But we should be very careful here, especially since Christianity (once again, the main religion in question) has many roots firmly in the pre-Enlightenment era. I think it is overstating the case to say, as Thiessen does, that recapturing the pre-Enlightenment respect for tradition is "at the heart of postmodernism." We should not forget that the pre-Enlightenment churches and European regimes were in many respects universalistic in orientation and often rode rough-shod over local traditions and communities, both in Europe and in other parts of the world. In many ways, postmodernism is as antithetical to the pre-Enlightenment era as to the modern era.

3. We must reach a compromise between acceptance of "epistemic communities" and pursuit of "common truth"

To some extent Thiessen tries to "have his cake and eat it too." On the one hand, he stresses the "institutional context" of inquiry (p. 7) and that "truth is found within epistemic communities" (p. 13); but, on the other hand, he emphasizes the need to avoid "epistemological relativism" and pursue a "common truth." He does not acknowledge sufficiently that our notion of truth must be radically revised in order to fit with the contextual nature of inquiry. The liberal notion of knowledge cannot survive the contextual view of inquiry Thiessen rightly wishes us to accept.

\section{We need more detail on how the constraints on academic freedom should work}

Thiessen says: "In religious schools with a healthy academic atmosphere, there will be both clearly defined limitations to academic freedom, as well as the freedom to think creatively on the basis of accepted religious commitments of the school." To me, this is paradoxical and requires considerable elaboration. It seems too optimistic about the possibility of being closed on some matters and open on others. Can different dimensions of knowledge be separated in this way? Further, I am not at all sure it is good procedure to try to define clearly the limitations to academic freedom: that smacks of legalism and credal conformity and is likely to induce hypocrisy and mere lip-service. If the constraint on freedom is to be a positive thing, as Thiessen wants, a support and guide in inquiry, it must normally reside in the sediment of the community's consciousness rather than in the clear light of day. Also, it will probably vary from individual to individual: people will need to understand the supportive concepts and assumptions differently at any given time, depending on the trajectory of their development. Undoubtedly, Thiessen wants the clarity so people know where they stand and can get on with their inquiry. But not only is this difficult and perhaps counterproductive; it can also lead to a whole new set of distracting activities concerned with interpreting the rules and second-guessing which will be enforced and under what circumstances. 
5. We need a radically new understanding of the role of religious educational institutions in today's world

Lying behind Thiessen's discussion of religious colleges and universities, there seems to be an image of a group of faculty and students with a fairly common religious commitment pursuing academic inquiry in relative isolation from other communities and institutions. This is implied especially by his claim that "truth is found within epistemic communities" and his suggestion that while the pluralism at secular universities is "primarily a plurality of individuals ... perhaps a healthier kind of pluralism could be found in a plurality of educational institutions, where each is committed to finding truth based on its particular standpoint"' (p. 13). Thiessen does say that the results of individual inquiry should be critiqued by people in other institutions; but there is still the assumption that within a religious institution truth would be pursued from a "particular standpoint," presumably the "faith stance" of the institution.

But, today, the people who teach and study at religiously-based educational institutions typically come from widely varying backgrounds, often from religions other than the official one; and they are going on (the students, at least) to widely varying ways of life. Even those faculty and students who belong to the official religion differ greatly in the degree and nature of their commitment to the religion. All have a wide array of connections to other institutions and communities beyond the one in question. Accordingly, it is difficult to see how the institution can have (a) a unitary religious standpoint, or (b) a standpoint that is clearly distinct from that of other educational institutions. Increasingly today people belong to many communities-that is, a professional society, a workplace community, a religious organization, a neighbourhood, a bealth or sporting club, a political action group, an alumni association, a book club, an extended family, a friendship group-rather than a single community, and they tailor their community memberships to suit their individual needs and circumstances. We have developed what might be called a "multi-communal" way of life, to coin a phrase.

What this means is that the official religion is only part-often quite a small part-of what gives a so-called "religious" institution its distinctive ethos. Many other distinctive emphases come simply from traditions which have been established over the years by the particular group of human beings who teach and study in the institution. One institution emphasizes multiculturalism, another feminism, another global awareness, another competitive sports, another the Great Books, another individual attainment, another co-operative learning, another the arts, and so on. These traditions bring with them assumptions and practices which constrain, guide, and support inquiry in just the ways Thiessen suggests. But they are only in part, if at all, constraints peculiar to the official religion of the institution.

This may lead to the question: Why call it a religious institution at all? Given all the distinctive characteristics of a particular educational institution, why pick on its religious affiliation as the basis for its name? And this is a good question and one to which I think Thiessen should give some attention. He does not seem sufficiently open to the possibility that in this pluralistic, inclusive age, educational institutions which are religiously-based in a strong sense may no longer be appropriate. But even if we say-as I am inclined to-that there is still a place for colleges and universities with a religious affiliation, for historical, 
cultural and community reasons among others, we should be more aware of how limited their distinctively religious dimension must be.

\section{We need much more discussion of particular substantive issues in academic freedom}

As it stands, Thiessen's paper is too abstract and procedural (although, as I have said, more detail is also needed on procedures). When he says it is legitimate for religious educational institutions to be "committed to a certain faith stance" and have "clearly defined limitations to academic freedom," what kind of commitments and limitations does he have in mind? We need some concrete examples. We might agree with him in theory but violently disagree on substance.

The only specific example Thiessen gives of a possible doctrinal commitment (and, hence, constraint) is that of belief in Jesus' divinity (p. 12). He discusses Father Charles Curran's assertion that "any Catholic theologian who does not accept Jesus' divinity . . . could be dismissed for incompetence." Thiessen sees this move by Curran as an attempt to cover up an inconsistency in his position on academic freedom, but he is nevertheless inclined to agree with Curran that it might be problematic for a professor in a Catholic seminary to adopt such a position.

But in my view, to insist that faculty-even theology faculty_in Catholic universities accept the divinity of Jesus is problematic in today's changing, pluralistic world. Even within the Christian community, many highly respected scholars do not regard Jesus as divine and who feel that such a belief is not essential to the Christian message or way of life. Some would even say that belief in the divinity of Jesus tends to alienate people from themselves, from each other and from nature. Beyond the Christian community, this doctrine can easily have very negative consequences. If Jesus is divine, what does that say about Moses, Buddha, Confucius, Muhammad? Coupled with the doctrine that there is only one God-namely, the Christian God-belief in the divinity of Jesus can undermine the attempt-regarded by many as essential-to move to a more pluralistic, inclusive understanding of religion and ways of life.

This is merely one example, and it is not clear what position Thiessen would actually take on it. For me, it points up a problem in Thiessen's paper: he does not acknowledge sufficiently the specific difficulties of academic freedom in religious colleges and universities today. It is all very well to argue in general terms that academic constraints in such institutions are not necessarily a problem. But everything depends on the kinds of constraints that are, in fact, imposed. At present, there are many problems in religious educational institutions with foot-dragging on such issues as the humanity of Jesus, creationism, acceptance of other religions, authoritarianism, the role of women, sexual morality, sexual persuasion, and so on.

It may be true, as Thiessen argues, that there are just as many problems in secular educational institutions. Further, insofar as there are problems in religious institutions, it may be best to try to solve them by processes within the institutions rather than through external threats to their academic status. But while insisting on the legitimacy of religious educational institutions, there should be more acknowledgement of current inappropriate forms of constraint in many such institutions, and a commitment to move in a more pluralistic, in- 
clusive direction. This might mean that the distinctively religious (in the sense of organized religion) ethos of such institutions would be reduced. But that too must be accepted in the changing, pluralistic world in which we live.

In conclusion, let me repeat that I found Professor Thiessen's paper both stimulating and insightful. My criticisms are intended to be constructive and not to detract from the essential soundness of his position. I agree that academic freedom need not be unduly curtailed in religiously-affiliated colleges and universities.

\section{Notes}

1 Elmer J. Thiessen, "Academic Freedom and Religious Colleges and Universities: Confronting the Postmodernist Challenge," Paideusis, 10(1), 1996, p. 3-16. Subsequent references to this article will be made in the form of page numbers inserted in the text.

2 Clive Beck, "Postmodernism, Pedagogy, and Philosophy of Education," in Philosophy of Education 1993 (Urbana, Illinois: The Philosophy of Education Society, 1993), 1-13; and "Postmodernism, Ethics, and Moral Education," in Wendy Kohli (ed.), Critical Conversations in Philosophy of Education (New York: Routledge, 1995), pp. 127-136.

${ }^{3}$ Charles W. Allen, "The Primacy of Phronesis: A Proposal for Avoiding the Frustrating Tendencies in Our Conceptions of Rationality," Journal of Religion, 69(3), 1989, pp. 359-374. 